\title{
The Effect of Pollution on Scope for Growth in the Pearl Oyster, Pteria aegyptiaca, in the Gulf of Aqaba, Jordan
}

\author{
Saleem Aladaileh ${ }^{1}$ \\ ${ }^{1}$ Biology Department, Al-Hussein Bin Talal University, Jordan \\ Correspondence: Saleem Aladaileh, Biology Department, Al-Hussein Bin Talal University, P.O. Box (20), Ma'an, \\ Jordan. Tel: 962-775-620-563. E-mail: sadaileh@ahu.edu.jo
}

Received: February 4, 2014 Accepted: March 2, 2014 Online Published: March 6, 2014

doi:10.5539/ijb.v6n2p120 URL: http://dx.doi.org/10.5539/ijb.v6n2p120

\begin{abstract}
This experiment was conducted to assess the effects of pollution on both the physiological and energetic characteristics (SFG) of Pteria aegyptiaca in the Gulf of Aqaba, Jordan. Four locations were chosen to represent both contaminated and uncontaminated locations. Phosphate Loading Berth (P) and the Industrial Area (I), represent contaminated locations, whilst the Hotels Area $(\mathrm{H})$ and Marine Science Station (M) represent uncontaminated locations. The results of this experiment showed that contaminated regions had significant effects $(\mathrm{P}<0.05)$ on respiration rate, clearance rate and absorption efficiency. A significant difference $(\mathrm{P}<0.05)$ was identified between the scopes for growth of animals transplanted in contaminated regions compared with animals from uncontaminated locations. The Phosphate Loading Berth (P) and Industrial Area (I), showed the lowest SFG $\left(18.7 \pm 4.591\right.$ and $35.94 \pm 7.412 \mathrm{Jh}^{-1}$ respectively), reduced to only a half of SFG compared to uncontaminated locations. Results from our study indicate that oysters exposed to contaminated regions are highly compromised in both their energetics and physiology. Failure to improve the environmental conditions in these regions may have catastrophic effects on the micro and macro fauna.
\end{abstract}

Keywords: scope for growth, pollution, Gulf of Aqaba, Pteria aegyptiaca

\section{General Introduction}

The study of anthropogenic effects on the environment has been shown to impact a wide range of ecosystems. An example of which is the accumulation of heavy metals within marine environments (Luoma, 1996). The expansion of industry worldwide has resulted in an increase of chemical discharge from mining, metal refining and processing industries into coastal environments (Widdows \& Donkin, 1992). Most of these pollutants have deleterious effects on the aquatic micro and macro fauna (Kennish, 1997).

The Gulf of Aqaba is highly abundant in marine organisms. Its tropical waters and diverse habitats are home of over 200 varieties of coral and more than 1000 species of subtropical fish (Atkinson et al., 2001; Alawneh, 1993). An increase in industrial activity and associated population has resulted in a flux of pollution into the estuarine and coastal environment. The pollution originates from a range of sources, including sewage, toxic materials from homes, factories, towns and cities (Phillips, 1980). Heavy metals and hydrocarbons are arguably the most toxic chemicals discharged into coastal environments. Sediments act as a large reservoir due to their ability to absorb heavy metals (Kennish, 1997). Phosphate, Diammonium phosphate fertilizer and potash are among the main sources of pollution in the Gulf of Aqaba. In 2012, the port of Aqaba exported $\sim 5 \times 106$ tons of phosphate ore (PLC, 2012). During the phosphate loading process, the estimated quantity of phosphate ore lost as fine particulate matter is $\sim 500$ tons/year (Atkinson et al., 2001). It is thought that this may cause an increase in the available nutrient supply to macroalgae and cyanobacteria. It is speculated that the abundance of nutrients may cause a phase-shift, from coral to algal dominated communities (Kuffner \& Paul, 2001; Done, 1992; Walker \& Ormond, 1982). Many studies have shown that the rate of necrosis in coral colonies has increased significantly in in the phosphate-polluted areas (Walker \& Ormond, 1982; Dunn et al., 2012).

Regions in the Gulf of Aqaba contain high levels of contaminants, which include phosphate, heavy metals and organocarbons (Youssef \& El-Said, 2011; Abu-Hilal, 1987; Abu-Hilal \& Badran, 1990). Pollution is detected in one of two ways. Firstly, contamination can be assessed directly by quantifying the amount of contaminants in the environment (Abu-Hilal, 1985; Abu-Hilal et al., 1988). The second method is to detect the direct effect of pollution on micro and macro fauna assemblages. Environmental stress has been found to affect the 
physiological function of many organisms (Díaz-Jaramillo et al., 2013; Dunn et al., 2012). Bivalve molluscs appear to be one of the most suitable groups to study the environmental stress, and have been the subject of many studies (Phillips, 1980; Navarro et al., 2013; Oyarzún et al., 2013). Bivalves are typically used to assess environmental conditions because they are widespread, easily obtained in large quantities, and they are sedentary. In addition to this, bivalves are filter feeders, which means they pass large volumes of water, resulting in the accumulation of many pollutants. However, it is difficult to measure a bivalve molluscs' growth and production directly because a large proportion of the total production can be lost in the form of gametes (Rueda \& Smaal, 2004). This issue is overcome by calculating the "scope for growth". The term scope for growth (SFG) was proposed and used by Warren and Davis (1967) to describe the energy retention and storage component in physiological energy balance studies (Warren \& Davis, 1967). Scope for growth (SFG) has been employed throughout many studies (Widdows, 1990; Navarro et al., 2013; Oyarzún et al., 2013; Prieto et al., 2012).

The current study investigates the effects of contaminated sediment on the physiology of organisms living on or within sediments. We also aim to compare the scope for growth of Pteria aegyptiaca (Dillwyn, 1817) transplanted to regions contaminated with phosphate, heavy metals, compared with non-contaminated habitats. In order to calculate SFG, clearance rate, absorption efficiency and respiration was recorded for both treatments.

\section{Material and Methods}

\subsection{Sample Preparation}

The winged pearl oyster $P$. aegyptiaca byssally attaches to rocks, corals, and other hard objects. It dwells from low tide levels to a depth of $30 \mathrm{~m}$ (Kent, 1998; Mastaller, 1987). This species of oyster is collected as a food resource and is also used for pearl production (production of half-pearls or mabe) in many countries around the world (Alagarswami et al., 1989). Two hundred adult P. aegyptiaca with anteroposterior shell sizes of 150 - 200 $\mathrm{mm}$ were randomly collected from the Gulf of Aqaba. The animals were cleaned with filtered sea water (FSW) using a brush to remove epiphytic growths and particulate matter from the shell surface. The shells were tagged using super glue and shellfish ID badges. After the glue had dried, animals were placed in an aquarium tank with 60 litres seawater for three days to recover from handling.

\subsection{Study Location and Experimental Design}

The Gulf of Aqaba in the northern Red Sea is a warm water body, approximately $160 \mathrm{~km}(99 \mathrm{mi})$ long and $24 \mathrm{~km}$ $(15 \mathrm{mi})$ wide, and attains a depth of about $1850 \mathrm{~m}$ in its central area. Four locations were selected to be representative of a contamination gradient (Figure 1). They were selected based on previous studies of the sources of contamination and chemical data (Al-Rousan et al., 2012; Al-Najjar et al., 2011). Phosphate Loading Berth (P) and Industrial Area (I) were chosen to represent contaminated locations. Hotels Area (H) and Marine Science Station (M) were chosen to represent uncontaminated locations. All these locations were chose to reflect the natural habitat of $P$. aegyptiaca. A nested sampling design was used in this study. To ensure sufficient replication, two sites were randomly selected within 20 meters of each other, and two cages were placed at each site.

\subsection{Cages and Cockles Deployment}

A total of sixteen plastic cages were deployed in July 2013. Cages were constructed of polypropylene mesh (mesh size $5 \times 5 \mathrm{~mm}$ ) and were barrel-like in structure with a diameter and height of $20 \mathrm{~cm}$. The cages were embedded into the benthic sediment and fixed into place using tent pegs. Once the cages were deployed, 10 animals were placed in each cage. The cages were then secured to prevent the entry of any predators. 


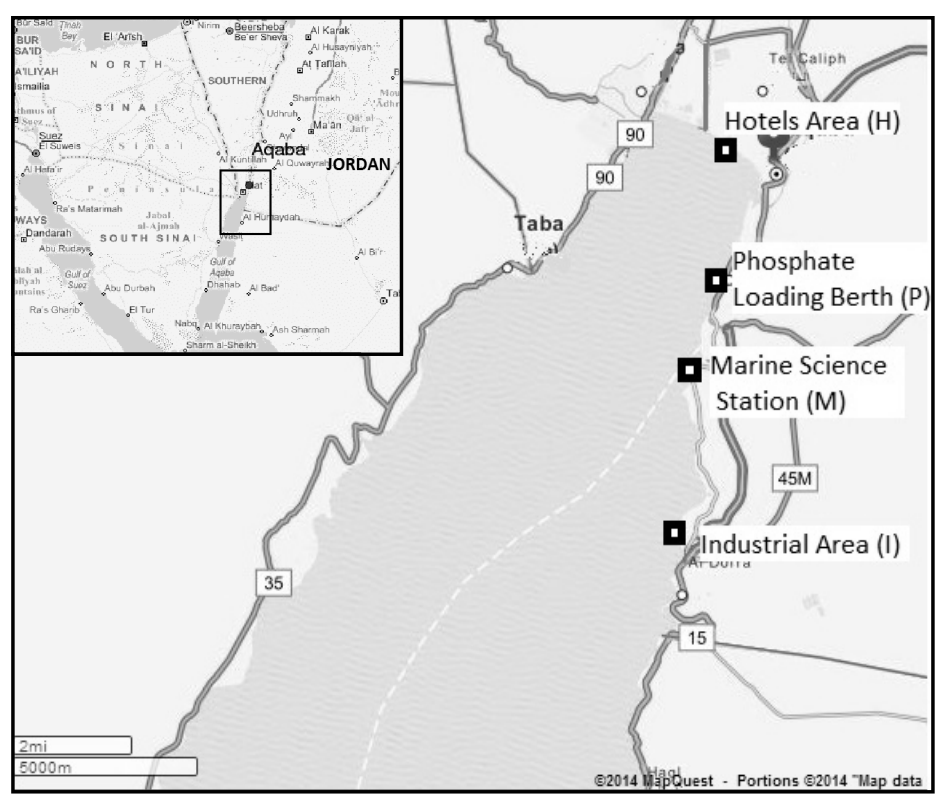

Figure 1. Map of four locations selected to be representative of a contamination gradient in the Gulf of Aqaba. Hotels Area (H), Marine Science Station (M), Phosphate Loading Berth (P), Industrial Area (I)

\subsection{Physiological Measurements}

Animals were collected for physiological measurement at the 29th of November 2012. Every second day animals from the four groups were collected and transferred under standard conditions to the laboratory. The oysters were housed in an aquarium containing 60 litres of recirculating sea water and were fed a mixture of algal cells. The mixture contained two species of algae, Nannochloropsis sp. and Tetraselmis sp. (Reed Mariculture Inc., USA). A twenty four hour recovery from aerial exposure, handling, and transport effects was allowed. Animals were carefully cleaned from fouling organisms. Five animals from each group were used for physiological measurement. Animals were only used in one measurement per day.

\subsection{Measurements of Physiological Components of Scope for Growth}

\subsubsection{Clearance Rate and Consumed Energy}

Clearance rate (CR) represents the volume of water cleared from particles per time unit measured in organisms from four locations. Seven plastic buckets each containing with 1 liter of filtered sea water (FSW) and a single oyster were used. A control bucket (without any animals) representing "treatment" was also used. The initial algal concentration in the bucket was relatively low, 30000 cells / $\mathrm{ml}$, in order to avoid the formation of the pseudo faeces. Water was gently aerated to keep the algae in suspension. Two samples were collected from each bucket every 30 minutes for 150 minutes. Cell concentrations were recorded as the average of two counts using a cell counter (hemocytometer). Clearance rate or the volume of water cleared of particles per unit of time $\left(\mathrm{Lh}^{-1}\right)$ by the animal was calculated using the following the equation (Coughlan, 1969):

$$
\mathrm{CR}=\mathrm{V}\left(\ln _{1}-\ln \mathrm{C}_{2}\right) / \mathrm{t}
$$

Where $\mathrm{CR}$ is the clearance rate, $\mathrm{V}$ is the volume of water used, $\mathrm{C}$ and $\mathrm{C}_{2}$ are the cell concentrations between two sampling times, and $\mathrm{t}$ is the time in hours (h).

The amount of consumed energy (C) can be calculated for each animal by multiplying the clearance rate (CR) by the amount of organic material (POM) per litre in each bucket at the beginning of each run and with the energy content of algal material, $23 \mathrm{~J} / \mathrm{Mg} / \mathrm{l}$ (Widdows et al., 1995). After the clearance rate was measured, the animals were returned to the aquarium to collect faeces for the absorption efficiency determination. 
The amount of particulate organic material (POM) per 10,000 algae was determined according to Oyarzún et al. (2013).

\subsubsection{Respiration Rate and Respired Energy (R)}

Respiration rate is often used to indicate stressful conditions and can be accurately measured. Rates of oxygen consumption were measured for each animal in closed and sealed respirometers of $600 \mathrm{ml}$. The decline in the oxygen rate within the chamber was recorded with a calibrated oxygen microelectrode inserted in the respirometer and connected to an Oxygen meter (Professional Dissolved Oxygen meter HD3030, Trans). Control measurements (without animal) were performed to ensure no drifting was caused by other factors. Chambers were completely filled with FSW and provided with magnetic stirring to ensure even distribution of oxygen. Oxygen run lasted for about $1.5 \mathrm{~h}$. Each run contained a random mixture of animals (treatment and control) collected from different sites. The rate of oxygen consumption was then calculated using the following equation:

$$
\mathrm{R}=\left[\mathrm{Ct}_{0}-\mathrm{Ct}_{1}\right] \times \mathrm{V} \times 60 /\left(\mathrm{t}_{1}-\mathrm{t}_{0}\right)
$$

Where $\mathrm{R}$ is the rate of oxygen uptake $\left(\mu \mathrm{MO}_{2} 1^{-1}\right), \mathrm{Ct}$ is the concentration of oxygen in the water $\left(\mu \mathrm{MO}_{2} 1^{-1}\right)$ at time $t, \mathrm{~V}$ is the volume of the water in the respirometer and $\mathrm{t} 0$ and $\mathrm{t} 1$ the initial and the end times (in minutes) of the measurement period.

\subsubsection{Absorption Efficiency}

The absorption efficiency (AE) represents the efficiency with which organic material is absorbed from ingested food material. To calculate the AE, the organic content of food and faeces need to be determined. The faeces of each animal were collected at the end of each experiment using $5 \mathrm{ml}$ syringe. The collected faeces were moved to the centrifuge tubes and centrifuged at $6000 \mathrm{rpm}$ for 10 minutes. The faecal matter was then washed with ammonium formate (38\%) to remove salt. The collected faeces were then centrifuged at $6000 \mathrm{rpm}$ for 10 minutes. The pellets were transferred to pre-weight $\left(\mathrm{W}_{1}\right)$ platinum crucibles and dried for 48 hours at $80{ }^{\circ} \mathrm{C}$ and transferred to a desiccator to cool to meet the room temperature and weighed $\left(\mathrm{W}_{2}\right)$. The samples were burnt overnight at $500{ }^{\circ} \mathrm{C}$ and weighed $\left(\mathrm{W}_{3}\right)$ after they cooled to room temperature. The amount of organic material $\left[\left(\mathrm{W}_{2}-\mathrm{W}_{3}\right) /\left(\mathrm{W}_{2}-\mathrm{W}_{1}\right)\right]$ was calculated. The absorption efficiency (AE) was calculated using the method of Conover (1966):

$$
\mathrm{AE}=(\mathrm{F}-\mathrm{E}) /[(1-\mathrm{E}) \times \mathrm{F}]
$$

Where $\mathrm{F}$ is the organic content of the food ingested and $\mathrm{E}$ is the organic content of the faeces.

\subsubsection{Correction for Body Weight}

Body weight is one of the important variables that affect most physiological responses. This effect can be removed by transplanting animals of similar body size and weight. After the physiological variables were measured, the animals employed in the experiments were dissected and the soft tissue were dried at $70{ }^{\circ} \mathrm{C}$ for 48 hours and then cooled and weighed. After that, they were burnt to ash overnight at $500{ }^{\circ} \mathrm{C}$ and weighed again.

All physiological rates were standardised to 1 gram dry weight following the formula of Bayne et al. (1987).

$$
\mathrm{Y}_{\mathrm{s}}=\left(\mathrm{W}_{\mathrm{s}} / \mathrm{W}_{\mathrm{e}}\right)^{\mathrm{b}} \times \mathrm{Y}_{\mathrm{e}}
$$

Where $Y_{s}$ is the physiological rate of an animal of standard weight, $W_{s}$ is the standard weight of animal, $Y_{e}$ is uncorrected (measured) physiological rate, $\mathrm{W}_{\mathrm{e}}$ is the observed weight of the animal, and $b$ is the exponent of allometric relationship between body mass And the rate of the physiological parameter. $b=0.66$ was used for respiration rate and clearance rate.

\subsubsection{Calculation of Scope for Growth}

The measured physiological rates were converted into energy equivalents $\left(\mathrm{J}^{-1} \mathrm{~h}^{-1}\right)$ and used in the balanced energy equation to calculate the energy available for growth and reproduction (SfG). Energy available for growth and reproduction was calculated by using the following equations: 
(C) is the energy consumed or ingested

$$
\mathrm{C}=\mathrm{CR} \times\left(\mathrm{mgPOMl}^{-1}\right) \times\left(23 \mathrm{~J} \mathrm{mg}^{-1} \mathrm{POM}\right)
$$

(A) is the energy absorbed $\mathrm{A}=(\mathrm{C}) \times$ absorption efficiency $(\mathrm{R})$ is the energy respired where $\mathrm{R}=\left(\mu\right.$ moles $\left.\mathrm{O}_{2} \mathrm{~g}^{-1} \mathrm{~h}^{-1}\right)$ $\times 0.456$

Where the heat equivalent of oxygen uptake is $0.456 \mathrm{~J}_{\mu} \mathrm{moles}^{-1} \mathrm{O}_{2}$

$(\mathrm{U})$ is the energy excreted

$$
\mathrm{U}=\left(\mu \text { moles } \mathrm{NH}_{4}-\mathrm{N} \mathrm{h}^{-1}\right) \text { is equivalent to an energy of } 0.349 \mathrm{Jh}^{-1}
$$

The rate of ammonia excretion is usually closely coupled to the respiration rate and forms a small proportion of metabolic energy expenditure. Therefore it was omitted from physiological energetic measurements and the calculation of scope for growth: $(\mathrm{P})$ is the Scope for Growth

$$
\mathrm{P}=\mathrm{A}-\mathrm{R}
$$

\subsection{Statistical Analyses}

One way analysis of variance (ANOVA) were carried out to test for treatment or location within treatment effects. The Newrnan-Keuls test was used to investigate which treatments were different and result in significant differences. No data transformation was used because the Cochran's test was not significant for all the data.

\section{Results}

\subsection{Clearance Rate}

As shown in Figure 2, the clearance rates of animals from the Phosphate Loading Berth $(\mathrm{P})$ and the Industrial Area (I) (contaminated locations) were $\sim 38 \%$ lower than the rates of animals from Hotels Area (H) Marine Science Station (M) (uncontaminated locations). This reduction was statistically significant (Figure 2) compared to $(\mathrm{H}),(\mathrm{M})$ and $(\mathrm{I})$. The $(\mathrm{P})$ was found to have the lowest feeding rate $(0.6505 \pm 0.2025)$.

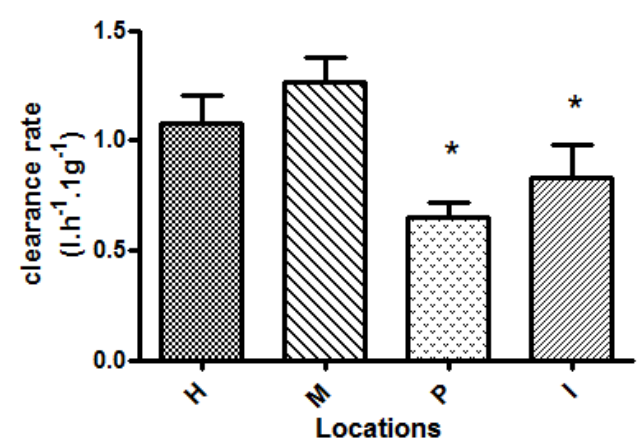

Figure 2. Clearance rate (mean $\pm \mathrm{SE}$ ) of Pteria aegyptiaca caged in four locations in the Gulf of Aqaba. Hotels Area $(\mathrm{H})$, Marine Science Station (M), Phosphate Loading Berth (P), Industrial Area (I). $n=5$, bars $=$ SEM. $\left(^{*}\right)$ indicates a significant difference from the uncontaminated locations $(\mathrm{H})$ and $(\mathrm{M})(\mathrm{P}<0.05)$

\subsection{Absorption Efficiency}

Absorption efficiencies of animals in the four locations were not significantly different (Figure 3). In addition, no significant effects were identified in the absorption efficiency of the "treatment" oysters. The average AE value was $\sim 0.595 \pm 0.017$ (mean $\pm \mathrm{SE}$ ). But the animals from the $(\mathrm{P})$, showed the lowest $\mathrm{AE}(0.4068 \pm 0.056)$. 


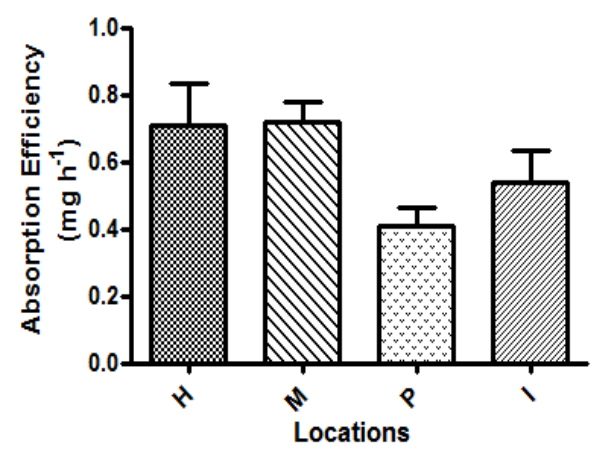

Figure 3. Absorption rate (mean $\pm \mathrm{SE}$ ) of Pteria aegyptiaca caged in four locations in the Gulf of Aqaba. Hotels Area (H), Marine Science Station (M), Phosphate Loading Berth (P), Industrial Area (I). n = 5, bars = SEM. $\left(^{*}\right)$ indicates a significant difference from the uncontaminated locations $(\mathrm{H})$ and $(\mathrm{M})(\mathrm{P}<0.05)$

\subsection{Respiration Rate}

Animals which were collected from $(\mathrm{H})$ and $(\mathrm{M})$ area showed similar rate of respiration (Figure 4). The difference between the controls vs. the treatment groups was significant. Animals at (I) showed the lowest respiration rates $12.96 \pm 1.602($ mean $\pm \mathrm{SE})$.

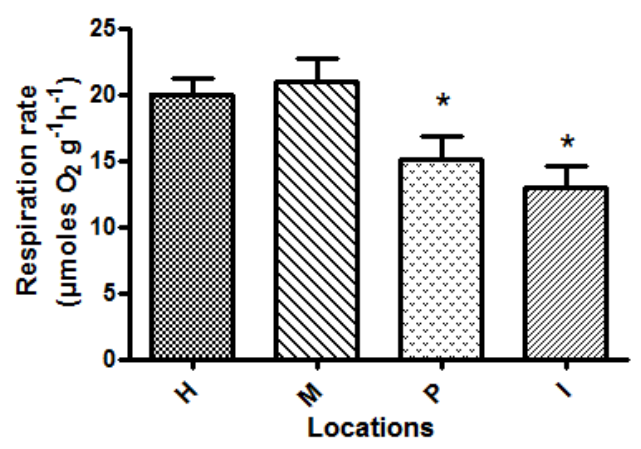

Figure 4. Respiration rate (mean $\pm \mathrm{SE}$ ) of Pteria aegyptiaca caged in four locations in the Gulf of Aqaba. Hotels Area $(\mathrm{H})$, Marine Science Station (M), Phosphate Loading Berth (P), Industrial Area (I). $n=5$, bars $=$ SEM. $\left(^{*}\right)$ indicates a significant difference from the uncontaminated locations $(\mathrm{H})$ and $(\mathrm{M})(\mathrm{P}<0.05)$

\subsection{Scope for Growth (SFG)}

Figure 5 demonstrates that positive values of SFG were recorded in all locations ranging between 18.7 to $77.25 \mathrm{~J}$ $\mathrm{h}^{-1}$. In this study, a significant difference $(\mathrm{P}<0.05)$ was found between the SFG of animals from $(\mathrm{H})$ and $(\mathrm{M})$ area and the animals from (P) and (Table 1). Even though the SFG was positive for all groups, oysters from the uncontaminated locations had SFG values twice as high as animals from contaminated locations. 


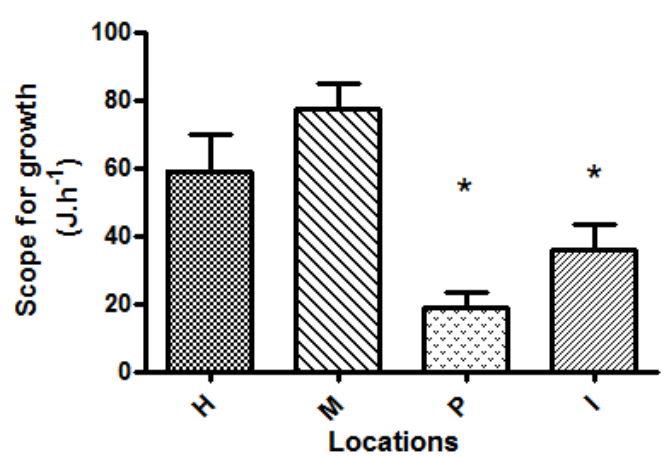

Figure 5. Scope for growth (mean $\pm \mathrm{SE}$ ) of Pteria aegyptiaca caged in four locations in the Gulf of Aqaba. Hotels Area (H), Marine Science Station (M), Phosphate Loading Berth (P), Industrial Area (I). $n=5$, bars $=$ SEM. $(*)$ indicates a significant difference from the uncontaminated locations $(\mathrm{H})$ and $(\mathrm{M})(\mathrm{P}<0.05)$

Table 1: Newman-Keuls Multiple Comparison Test

\begin{tabular}{ccccc}
\hline Newman-Keuls Multiple Comparison Test & Mean Diff. & Q & Significant? P $<\mathbf{0 . 0 5 ?}$ & Summary \\
\hline P VS M & -58.55 & 7.397 & Yes & $* * *$ \\
P VS H & -40.38 & 5.101 & Yes & $* *$ \\
P VS I & -17.24 & 2.178 & No & $\mathrm{ns}$ \\
I VS M & -41.31 & 5.219 & Yes & $* *$ \\
I VS H & -23.14 & 2.923 & Yes & $*$ \\
H VS M & -18.17 & 2.296 & No & $\mathrm{ns}$ \\
\hline
\end{tabular}

Results of Newman-Keuls Multiple Comparison Test, testing the effects of pollution, Scope for growth (SFG) of Pteria aegyptiaca caged in four locations in the Gulf of Aqaba. Hotels Area (H), Marine Science Station (M), Phosphate Loading Berth (P), Industrial Area (I). $\left(^{*}\right)$ indicates a significant difference.

\section{Discussion}

This experiment was conducted to assess how heavy metal stressors affect the physiological and energetic functions in P. aegyptiaca. Results from this study indicate that animals transplanted to contaminated locations have lower SFG compared to the uncontaminated locations. The animals at $(\mathrm{M})$ were found to have faster clearance rates than animals from (H), (P) and (I). Both the Phosphate Loading Berth (P) and (I) had the lowest clearance rates. The clearance rate is an important component in the calculation of the energy budget and is very sensitive to a wide range of chemical contaminants and stressors (Echevarria et al., 2012; Sanders et al., 2013; Widdows et al., 1990; Sarà et al., 2000). It has been demonstrated that the reduction in energy acquisition is primarily due to a reduced clearance rate and enhanced respiration rate (Widdows \& Page, 1993; Widdows et al., 1990).

The most significant difference in physiological responses recorded was the clearance rate. Scope for growth showed the pattern similar to that of clearance rate; therefore measuring SFG is occasionally simplified to measuring clearance (Ostroumov \& Widdows, 2006; Donkin et al., 1989; Donkin et al., 1997). However, the determination of clearance rate as a single physiological parameter does not have the same power of discrimination as the more complete and integrated measure termed SFG. Many studies indicate that clearance rate does not depend on the changes in many environmental factors including water temperature and salinity (Sarà et al., 2000). In addition to that, these studies have shown that CR is influenced by seasonal changes in terms of the quality and quantity of available food (Sarà et al., 2000).

A significant decrease in respiration rate observed in oysters from the $(\mathrm{P})$ and $(\mathrm{I})$. This decrease may result of reduction in feeding activity. A similar pattern of respiration rate has been described in many bivalve species, such as Cerastoderma edule (Nilin et al., 2012). However, the animal response may vary depending on species, pollutant type and concentration (Bayne, 1980; Widdows et al., 1990). Results of this study do not agree with those of Burt et al. (2007) who showed an increase in the oxygen consumption after 90 days of exposure in 
Anadara trapezia that were transplanted in metal contaminated location (Burt et al., 2007). Wang et al. (2005) also showed that respiration rate is less sensitive than other physiological responses (Wang et al., 2005).

The feeding response provides an initial indication of physiological stress which may lead to growth retardation (Sheehan, 1984). The treatment sites were shown to have a significant effect on the absorption efficiency. The efficiency with which food material is absorbed by the digestive system can be altered by many environmental factors, the type of and condition of the animal, the quantity and organic content, and the quantity and quality of food (Newell \& Bayne, 1980; Bayne et al., 1993). Animals at all locations had a similar absorption efficiency, which can be explained by the insensitivity of absorption efficiency for the pollutant. The absorption efficiency was found relatively high (H: $0.7095 \pm 0.1256, \mathrm{M}: 0.7178 \pm 0.06241, \mathrm{P}: 0.4068 \pm 0.05622$, I: $0.5397 \pm 0.09113$ $\mathrm{mg} \mathrm{h}^{-1}$ ) in this experiment in all locations. These values can be interpreted by a good quality and quantity of food in the Gulf of Aqaba. Several bivalve species have also demonstrated that absorption is independent of seston concentration; however, it is dependent on the seston quality, or percentage of organics (Bayne et al., 1993; Denis et al., 1999). These results are not comparable to results obtained in other studies, where the absorption efficiency decreased in the presence of contaminants (Widdows et al., 1987).

The values for SFG shown in this study were relatively high when compared with those published by others (Navarro \& Gonzalez, 1998; Navarro \& Contreras, 2010). Negative SFG values indicate that the animals are under severe stress conditions where they do not gain enough energy to survive (Bayne et al., 1985). The mean value for SFG was $47.75 \pm 10.03 \mathrm{~J} \mathrm{Jh}^{-1}$. It can be concluded that the animals were under mild stress in all the locations and we can explain that by the low level of the contaminants in all the locations. The SFG of animals living at $(\mathrm{M})$ and $(\mathrm{H})$ were significantly higher than animals at $(\mathrm{P})$ and $(\mathrm{I})$. This may be due to the relatively high levels of phosphate and heavy metals in (P) and (I). The observed decline in SFG of animals transplanted in the contaminated locations was mainly due to a slower clearance rate. Differences between treatments were significant (Figure 5). These differences may be explained by the low value of SFG for the oysters at (P). The value was low in comparison with those at other locations. That may be due to the presence of disturbance; at this location there was high concentration of phosphate and also a large number of ships, and as a result, two cages were lost at this location but not all the animals were found dead but embedded in the sediment.

\section{Conclusions}

Physiological responses can be used as general indices to demonstrate the effects of pollution as they are directly associated with the health of individual animals (Bayne, 1980). The results of this experiment showed that contaminated regions had significant effects $(\mathrm{P}<0.05)$ on respiration rate, clearance rate and absorption efficiency However, it would be useful to examine the effect of physical disturbances on the SFG. Concentrations of contaminants in the tissues of the animals should also be examined to determine how they correlate to Scope for Growth.

\section{Acknowledgements}

This research was funded by Al-Hussien Bin Talal University in Jordan. I would like to express my deep gratitude to Dr. Saber Al-Rousan for the invaluable assistance in collecting and processing specimens.

\section{References}

Abu-Hilal, A. H., Badran, M. M., \& de Vaugelas, J. (1988). Distribution of trace elements in Callichirus laurae burrows and nearby sediments in the gulf of Aqaba, Jordan (Red Sea). Marine Environmental Research, 25(4), 233-248. http://dx.doi.org/10.1016/0141-1136(88)90014-1

Abu-Hilal, A. H. (1985). Phosphate pollution in the Jordan Gulf of Aqaba. Marine Pollution Bulletin, 16(7), 281-285. http://dx.doi.org/10.1016/0025-326X(85)90567-3

Abu-Hilal, A. H. (1987). Distribution of trace elements in nearshore surface sediments from the Jordan Gulf of


http://dx.doi.org/10.1016/0025-326X(87)90245-1

Abu-Hilal, A. H., \& Badran, M. M. (1990). Effect of pollution sources on metal concentration in sediment cores from the Gulf of Aqaba (red sea). Marine Pollution Bulletin, 21(4), 190-197. http://dx.doi.org/10.1016/0025-326X(90)90501-X

Al-Najjar, T., Rasheed, M., Ababneh, Z., Ababneh, A., \& Al-Omarey, H. (2011). Heavy metals pollution in sediment cores from the Gulf of Aqaba, Red Sea. Natural science, 3(9). http://dx.doi.org/10.4236/ns.2011.39102 
Al-Rousan, S., Al-Shloul, R., Al-Horani, F., \& Abu-Hilal, A. (2012). Heavy metals signature of human activities recorded in coral skeletons along the Jordanian coast of the Gulf of Aqaba, Red Sea. Environmental Earth Sciences, 67(7), 2003-2013. http://dx.doi.org/10.1007/s12665-012-1640-0

Alagarswami, K., Dharmaraj, S., Chellam, A., \& Velayudhan, T. S. (1989). Larval and juvenile rearing of black-lip pearl oyster, Pinctada margaritifera (Linnaeus). Aquaculture, 76(1-2), 43-56. http://dx.doi.org/10.1016/0044-8486(89)90250-0

Alawneh, Z. J. (1993). Jordanian environmental laws, institutions, and treaties affecting the gulf of aqaba. In D. Sandler, E. Adly \& M. A. Al-Khoshman (Eds.), Protecting the Gulf of Aqaba: A Regional Environmental Challenge. Environmental Law Inst.

Atkinson, M. J., Birk, Y., \& Rosenthal, H. (2001). Evaluation of Pollution in the Gulf of Eilat. Report For the Ministries of Infrastructure, Environment and Agriculture.

Bayne, B. L. (1980). Physiological measurements of stress (Vol 197). Rapp. P. V. Reun. Cons. Int. Explor. Mer.

Bayne, B. L., Brown, D. A., Burns, K., Dixon, D. R., Ivanovici, A., Livingstone, D. R., ... Widdows, J. (1985). Effects of Stress and Pollution on Marine Animals., Westport, CT: Greenwood Press.

Bayne, B. L., Hawkins, A. J. S., \& Navarro, E. (1987). Feeding and digestion by the mussel Mytilus edulis L. (Bivalvia: Mollusca) in mixtures of silt and algal cells at low concentrations. Journal of Experimental Marine Biology and Ecology, 111(1), 1-22. http://dx.doi.org/10.1016/0022-0981(87)90017-7

Bayne, B. L., Iglesias, J. I. P., Hawkins, A. J. S., Navarro, E., Heral, M., \& Deslous-Paoli, J. M. (1993). Feeding behaviour of the mussel, Mytilus edulis: Responses to variations in quantity and organic content of the seston. Journal - Marine Biological Association of the United Kingdom, 73(4), 813-829. http://dx.doi.org/10.1017/S0025315400034743

Burt, A., Maher, W., Roach, A., Krikowa, F., Honkoop, P., \& Bayne, B. (2007). The accumulation of Zn, Se, Cd, and $\mathrm{Pb}$ and physiological condition of Anadara trapezia transplanted to a contamination gradient in Lake Macquarie, New South Wales, Australia. Marine Environmental Research, 64(1), 54-78. http://dx.doi.org/10.1016/j.marenvres.2006.12.009

Coughlan, J. (1969). The estimation of filtering rate from the clearance of suspensions. Marine Biology, 2, 356-358. http://dx.doi.org/10.1007/BF00355716

Denis, L., Alliot, E., \& Grzebyk, D. (1999). Clearance rate responses of Mediterranean mussels, Mytilus galloprovincialis, to variations in the flow, water temperature, food quality and quantity. Aquatic Living Resources, 12(4), 279-288. http://dx.doi.org/10.1016/S0990-7440(00)86639-5

Díaz-Jaramillo, M., Socowsky, R., Pardo, L. M., Monserrat, J. M., \& Barra, R. (2013). Biochemical responses and physiological status in the crab Hemigrapsus crenulatus (Crustacea, Varunidae) from high anthropogenically-impacted estuary (Lenga, south-central Chile). Marine Environmental Research, 83, 73-81. http://dx.doi.org/10.1016/j.marenvres.2012.10.012

Done, T. J. (1992). Phase shifts in coral reef communities and their ecological significance. Hydrobiologia, 247(1-3), 121-132. http://dx.doi.org/10.1007/BF00008211

Donkin, P., Widdows, J., Evans, S. V., Staff, F. J., \& Yan, T. (1997). Effect of neurotoxic pesticides on the feeding rate of marine mussels (Mytilus edulis). Pesticide Science, 49(2), 196-209. http://dx.doi.org/10.1002/(SICI)1096-9063(199702)49:2\%3C196::AID-PS495\%3E3.0.CO;2-C

Donkin, P., Widdows, J., Evans, S. V., Worrall, C. M., \& Carr, M. (1989). Quantitative structure-activity relationships for the effect of hydrophobic organic chemicals on rate of feeding by mussels (Mytilus edulis). Aquatic Toxicology, 14(3), 277-294. http://dx.doi.org/10.1016/0166-445X(89)90021-0

Dunn, J. G., Sammarco, P. W., \& LaFleur, G. (2012). Effects of phosphate on growth and skeletal density in the scleractinian coral Acropora muricata: A controlled experimental approach. Journal of Experimental Marine Biology and Ecology, 411, 34-44. http://dx.doi.org/10.1016/j.jembe.2011.10.013

Echevarria, M., Naar, J. P., Tomas, C., \& Pawlik, J. R. (2012). Effects of Karenia brevis on clearance rates and bioaccumulation of brevetoxins in benthic suspension feeding invertebrates. Aquatic Toxicology, 106-107, 85-94. http://dx.doi.org/10.1016/j.aquatox.2011.10.011

Kennish, M. J. (1997). Heavy metals. In M. J. Kennish \& P. L. Lutz (Eds.), Practical Handbook of Estuarine and Marine Pollution (pp 253-329). Boca Raton, Florida: CRC Press. 
Kent, E. C. (1998). FAO Species Identification Guide for Fishery Purposes. The Living Marine Resources of the Western Central Pacific, Volume 1: Seaweeds, corals, bivalves and gastropods. Rome: Food and Agriculture Organization of the United Nations.

Kuffner, I. B., \& Paul, V. J. (2001). Effects of nitrate, phosphate and iron on the growth of macroalgae and benthic cyanobacteria from cocos lagoon, guam. Marine Ecology Progress Series, 222, 63-72. http://dx.doi.org/10.3354/meps222063

Luoma, S. N. (1996). The developing framework of marine ecotoxicology: Pollutants as a variable in marine ecosystems? Journal of Experimental Marine Biology and Ecology, 200(1-2), 29-55. http://dx.doi.org/10.1016/S0022-0981(96)02679-2

Mastaller, M. (1987). CHAPTER 10 - Molluscs of the Red Sea. In A. J. Edwards \& S. M. Head (Eds.), Red Sea. Pergamon (pp. 194-214). Amsterdam. http://dx.doi.org/10.1016/B978-0-08-028873-4.50015-3

Navarro, J. M., \& Contreras, A. M. (2010). An integrative response by Mytilus chilensis to the toxic dinoflagellate Alexandrium catenella. Marine Biology, 157(9), 1967-1974. http://dx.doi.org/10.1007/s00227-010-1465-x

Navarro, J. M., \& Gonzalez, C. M. (1998). Physiological responses of the Chilean scallop Argopecten purpuratus to decreasing salinities. Aquaculture, 167(3-4), 315-327. http://dx.doi.org/10.1016/S0044-8486(98)00310-X

Navarro, J. M., Torres, R., Acuña, K., Duarte, C., Manriquez, P. H., Lardies, M., ... Aguilera, V. (2013). Impact of medium-term exposure to elevated pCO2 levels on the physiological energetics of the mussel Mytilus chilensis. Chemosphere, 90(3), 1242-1248. http://dx.doi.org/10.1016/j.chemosphere.2012.09.063

Newell, R. I. E., \& Bayne, B. L. (1980). Seasonal changes in the physiology, reproductive condition and carbohydrate content of the cockle Cardium (Cerastoderma) edule (Bivalvia: Cardiidae). Marine Biology, 56(1), 11-19. http://dx.doi.org/10.1007/BF00390589

Nilin, J., Pestana, J. L. T., Ferreira, N. G., Loureiro, S., Costa-Lotufo, L. V., \& Soares, A. M. V. M. (2012). Physiological responses of the European cockle Cerastoderma edule (Bivalvia: Cardidae) as indicators of coastal lagoon pollution. Science of the Total Environment, 435-436, 44-52. http://dx.doi.org/10.1016/j.scitotenv.2012.06.107

Ostroumov, S. A., \& Widdows, J. (2006). Inhibition of mussel suspension feeding by surfactants of three classes. Hydrobiologia, 556(1), 381-386. http://dx.doi.org/10.1007/s10750-005-1200-7

Oyarzún, P. A., Toro, J. E., \& Navarro, J. M. (2013). Comparison of the physiological energetics between Mytilus chilensis, Mytilus galloprovincialis and their hybrids, under laboratory conditions. Aquaculture Research, 44(12), 1805-1814. http://dx.doi.org/10.1007/s10750-005-1200-7

Phillips, D. J. H. (1980). Quantitative aquatic biological indicators: Their use to monitor trace metal and organochlorine pollution. London: Applied Science Publishers.

PLC. JPMC. (2012). Jordan Phosphate Mines Company P.L.C. Annual Report Amman.

Prieto, D., Urrutxurtu, I., Ibarrola, I., Urrutia, M. B., \& Navarro, E. (2012). Effect of the ashes produced in forest fires in the physiological energetics of Mytilus galloprovincialis. Comparative Biochemistry and Physiology Part A: Molecular \& Integrative Physiology, 163 Supplement(0), 660. http://dx.doi.org/10.1016/j.cbpa.2012.05.177

Rueda, J. L., \& Smaal, A. C. (2004). Variation of the physiological energetics of the bivalve Spisula subtruncata (da Costa, 1778) within an annual cycle. Journal of Experimental Marine Biology and Ecology, 301(2), 141-157. http://dx.doi.org/10.1016/j.jembe.2003.09.018

Sanders, T., Widdicombe, S., Calder-Potts, R., \& Spicer, J. I. (2013). Environmental hypoxia but not minor shell damage affects scope for growth and body condition in the blue mussel Mytilus edulis (L.). Marine Environmental Research. http://dx.doi.org/10.1016/j.marenvres.2013.12.013

Sarà, G., Romano, C., Caruso, M., \& Mazzola, A. (2000). The new Lessepsian entry Brachidontes pharaonis (Fischer P., 1870) (Bivalvia, Mytilidae) in the western Mediterranean: A physiological analysis under varying natural conditions. Journal of Shellfish Research, 19(2), 967-977.

Sheehan, P. J. (1984). Effects on Individuals and Populations. In P. J. Sheehan, D. R. Miller, G. C. Butler \& P. Bourdeau (Eds.), Effects of Pollutants at the Ecosystem Level (pp 23-50). John Wiley \& Sons Ltd. 
Walker, D. I., \& Ormond, R. F. G. (1982). Coral death from sewage and phosphate pollution at Aqaba, Red Sea. Marine Pollution Bulletin, 13(1), 21-25. http://dx.doi.org/10.1016/0025-326X(82)90492-1

Wang, S., Hong, H., \& Wang, X. (2005). Bioenergetic responses in green lipped mussels (Perna viridis) as indicators of pollution stress in Xiamen coastal waters, China. Marine Pollution Bulletin, 51(8-12), 738-743. http://dx.doi.org/10.1016/j.marpolbul.2005.02.024

Warren, C., \& Davis, G. (1967). Laboratory studies on the feeding, bioenergetics and growth of fish. In S. D. G. (Ed.), The biological basis of freshwater fish production (pp. 175-214). Oxford: Blackwell Scientific Publications.

Widdows, J. (1990). Measurement of physiological energetics (scope for growth) and chemical contaminants in mussels (Arca zebra) transplanted along a contamination gradient in Bermuda. Journal of Experimental Marine Biology and Ecology, 138(1-2), 99-117. http://dx.doi.org/10.1016/0022-0981(90)90179-G

Widdows, J., Burns, K. A., Menon, N. R., Page, D. S., \& Soria, S. (1990). Measurement of physiological energetics (scope for growth) and chemical contaminants in mussels (Arca zebra) transplanted along a contamination gradient in Bermuda. Journal of Experimental Marine Biology and Ecology, 138(1-2), 99-117. http://dx.doi.org/10.1016/0022-0981(90)90179-G

Widdows, J., \& Donkin, P. (1992). Mussels and environmental contaminants: Bioaccumulation and physiological aspects. In E. G. (Ed.), The mussel Mytilus: Ecology, physiology, genetics and culture (pp. 383-424). Amsterdam: Elsevier.

Widdows, J., Donkin, P., Brinsley, M. D., Evans, S. V., Salkeld, P. N., Franklin, A., ... Waldock, M. J. (1995). Scope for growth and contaminant levels in North Sea mussels Mytilus edulis. Marine Ecology Progress Series ,127(1-3), 131-148. http://dx.doi.org/10.3354/meps127131

Widdows, J., Donkin, P., \& Evans, S. V. (1987). Physiological responses of Mytilus edulis during chronic oil exposure and recovery. Marine Environmental Research, 23(1), 15-32. http://dx.doi.org/10.1016/0141-1136(87)90014-6

Widdows, J., \& Page, D. S. (1993). Effects of tributyltin and dibutyltin on the physiological energetics of the mussel, Mytilus edulis. Marine Environmental Research, 35(3), 233-249. http://dx.doi.org/10.1016/0141-1136(93)90096-I

Youssef, D. H., \& El-Said, G. F. (2011). Assessment of some heavy metals in surface sediments of the Aqaba Gulf, Egypt. Environmental Monitoring and Assessment, 180(1-4), 229-242. http://dx.doi.org/10.1007/s10661-010-1784-x

\section{Copyrights}

Copyright for this article is retained by the author(s), with first publication rights granted to the journal.

This is an open-access article distributed under the terms and conditions of the Creative Commons Attribution license (http://creativecommons.org/licenses/by/3.0/). 